N-JILS Vol.3 No.1 2020

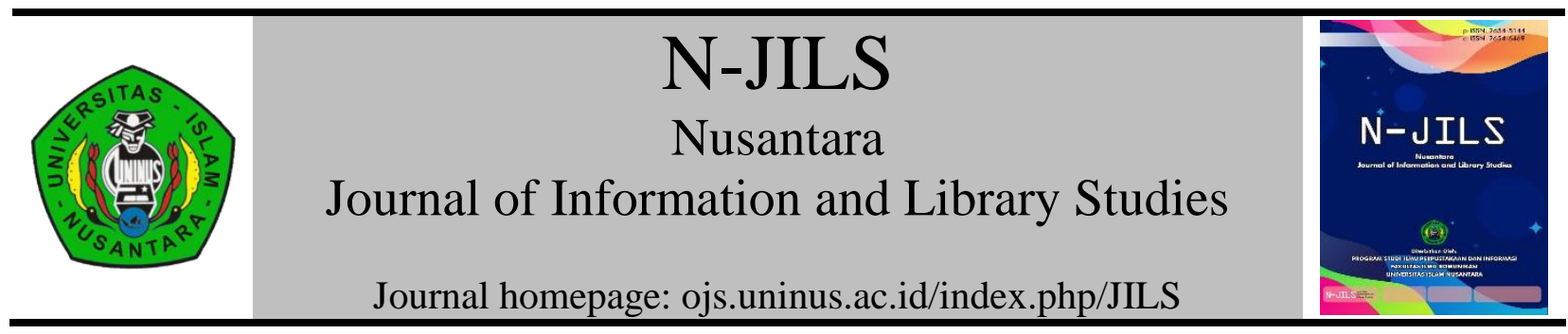

\title{
Taman Baca Tanah Ombak Dalam Meningkatkan Literasi Baca Anak Di Pantai Purus
}

\section{Tanah Ombak Reading Park In Improving Children's Literacy Reading At Purus Beach}

\author{
Aulia Fadila \\ Program Studi Perpustakaan dan Ilmu Informasi, Universitas Negeri Padang \\ e-mail: auliafadila736@gmail.com
}

\begin{tabular}{ll}
\hline ARTICLE INFO & ABSTRACT \\
\hline Article history & This research was conducted in Tanah Ombak Reading \\
Received [May 2020] & Park, Purus III Village, Padang City, West Sumatra. This \\
Accepted [June 2020] & study aims to illustrate that Tanah Ombak reading park has \\
Available Online [June 2020] & a considerable influence in changing the stigma and views \\
& of the community around Purus Beach which is very far \\
& from the reading material and has bad behavior. This is \\
& where the role played by the Tanah Ombak Reading Park to \\
& make the children of the Purus Beach community have good \\
& character and good literacy too. This research uses \\
& descriptive research method using a qualitative approach. \\
& The purpose of descriptive research is to provide a \\
& description based on accurate facts obtained in the field. \\
& The subjects in this study were children who lived around \\
& Tanah Ombak Reading Park, while the object of the study \\
& was Tanah Ombak Reading Park, Padang, West Sumatra. \\
& Data collection techniques carried out by observation,
\end{tabular}


interviews and literature. The informants in this study amounted to one person, Mr. Yusrizal. The results of this study are (1) children's reading literacy and society will develop well if the elements that play a role in the scope understand their respective roles (2) many activities held by Tanah Ombak Reading Park to improve reading literacy(3) Tanah Ombak Reading Park has various awards from other renowned institutions and artists. (4) the obstacle felt by Tanah Ombak Reading Park is the lack volunteers so the activities are not well structured. So it can be concluded that Tanah Ombak reading Park has a positive impact in providing education and teaching to children such as learning to count, draw, tell stories, play, and most importantly teach norms in society. However, all activities are constrained due to the limited volunteers so that the activities are only carried out by children independently, such as reading books by themselves without being accompanied by volunteers. Suggestion for the future that Tanah Ombak Reading Park informs the public about the needs of volunteers so that the activities in Tanah Ombak Reading Park can take place in a structured manner.

Kata kunci: taman baca, Tanah Keyword: Reading Park, Tanah Ombak, Literacy, childrens.

\section{ABSTRAK}

Penelitian ini dilakukan di Taman Baca Tanah Ombak, Kampung Purus III, Kota Padang, Sumatera Barat. Penelitian ini bertujuan untuk memberikan gambaran bahwa Taman Baca Tanah Ombak memiliki pengaruh yang cukup besar dalam mengubah stigma dan pandangan masyarakat disekitar Pantai Purus yang sangat jauh dari bahan bacaan serta perilaku yang kurang baik. Disinilah peran yang dimainkan Taman Baca Tanah Ombak untuk menjadikan anak-anak dan masyarakat Pantai Purus lebih berkarakter dan memiliki literasi yang bagus. Penelitian ini menggunakan metode penelitian deskriptif menggunakan pendekatan kualitatif. Tujuan penelitian deskriptif adalah 
memberikan gambaran berdasarkan fakta yang akurat yang didapat dilapangan. Subjek dalam penelitian ini adalah anak-anak yang tinggal di sekitar Taman Baca Tanah Ombak, sedangkan objek penelitiannya adalah Taman Baca Tanah Ombak, Padang, Sumatera Barat. Teknik pengumpulan data dilakukan dengan cara observasi, wawancara dan kepustakaan. Informan dalam penelitian ini berjumlah satu orang yaitu Bapak Yusrizal. Hasil dari penelitian ini adalah (1) literasi baca anak dan masyarakat akan berkembang dengan baik jika elemen yang berperan dalam lingkup tersebut memahami perannya masingmasing (2) banyak kegiatan yang diadakan oleh Taman Baca Tanah Ombak dalam meningkatkan literasi baca (3) Taman Baca Tanah Ombak memiliki berbagai penghargaan dari lembaga dan artis ternama lainnya (4) kendala yang dirasakan Taman Baca Tanah Ombak ini adalah kurangnya relawan sehingga kegiatan tidak terstruktur dengan baik. Jadi dapat disimpulkan bahwa Taman Baca Tanah Ombak berdampak positif dalam memberikan pendidikan dan pengajaran kepada anak-anak seperti belajar berhitung, menggambar, berdongeng, bermain dan yang paling penting mengajarkan norma-norma dalam bermasyarakat. Namun semua kegiatannya terkendala dikarenakan terbatasnya relawan sehingga kegiatan hanya dilakukan oleh anak-anak secara mandiri, seperti membaca buku sendiri tanpa didampingi relawan. Saran untuk kedepannya agar Taman Baca Tanah Ombak memberitahukan kepada khalayak umum mengenai kebutuhan tenaga relawan agar kegiatan di Taman Baca Tanah Ombak dapat berlangsung dengan terstruktur.

(c) 2020 NJILS. All rights reserved. 


\section{A. PENDAhuluan}

Indonesia adalah salah satu negara yang termasuk ke dalam daftar negara yang padat penduduk. Dilihat dari sisi lain hal ini bukanlah suatu masalah namun dapat dijadikan sebagai ciri khas negara kita yaitu negara yang beragam jenis agama, suku, budaya, bahasa, pulau, ras, jenis kulit dan lain sebagainya. Namun sangat disayangkan jika negara yang padat penduduk ini memiliki pengetahuan dan wawasan yang sangat sedikit, seperti yang dilansir di detik.com yang menyatakan bahwa Indonesia berada pada level bawah pada survei kelas dunia. Hasil penelitian dari Program for International Student Assessment (PISA) tahun 2015 dan World's Most Literate Nations' dari Central Connecticut State University (CCSU) pada Maret 2016. Penelitian PISA menunjukan Indonesia berada pada rangking 62 dari 72 negara namun 2 diantaranya yaitu Malaysia dan Kazakhstan tidak memenuhi kualisifikasi penelitian. Respondennya terdiri dari anak-anak sekolah berusia 15 tahun, jumlahnya sekitar 540 ribu anak. Skor Indonesia untuk sains adalah 403, untuk membaca 397, dan untuk matematika 386. Negara yang menempati rangking 1 adalah Singapura dengan skor sains 556, membaca 535 dan matematika 564. Disusul Jepang dan urutan ke-3 oleh negara Estonia.

Sedangkan menurut penelitian CCSU menyatakan Indonesia berada pada urutan ke-60 dari 61 negara yang di survei. Survei ini berdasarkan pada lima indikator yakni perpustakaan, surat kabar, pendidikan dan ketersediaan komputer. Berdasarkan penelitian ini Indonesia masih unggul dari satu negara yaitu Botswana. Terpuruknya literasi Indonesia di mata dunia menjadi masalah penting bagi pemerintah dan seluruh jajarannya termasuk para mahasiswa. Jalan keluar permasalahan ini akan ditemukan apabila semua elemen menyadari betapa pentingnya literasi baca untuk anak-anak generasi bangsa.

Rendahnya literasi baca anak-anak Indonesia bukan semata-mata adalah salah anak-anak Indonesia yang tidak suka membaca. Namun perlu diteliti apa penyebab pasti dari rendahnya minat baca di Indonesia. Ada dua faktor yang mempengaruhi literasi anak yaitu faktor yang berasal dari dalam (internal) diri siswa seperti: faktor keturunan, minat, bakat, IQ dan sebagainya. Dan faktor yang berasal dari luar (eksternal) siswa seperti motivasi, keluarga, bimbingan belajar (les), bimbingan belajar saat menempuh pendidikan TK dan sebagainya (Saputri, Fauziah, \& Nurhaidah , 2017). 
Berdasarkan asumsi penulis faktor lainnya dapat berupa sulitnya akses anak-anak dalam mendapatkan buku untuk dibaca. Hal itu bisa dikarenakan faktor ekonomi, akses terhadap buku yang sangat sulit serta tempat tinggal mereka yang jauh di pedalaman menjadikan membaca bukanlah kebutuhan utama. Jika aksesnya untuk memiliki buku sulit bagaimana anak-anak akan senang membaca? Faktor lainnya ialah kurangnya uluran tangan dan partisipasi kita dalam menyalurkan buku ke daerah-daerah terpencil yang sulit ditemui buku untuk anak-anak seperti buku dongeng, buku cerita, cerpen, puisi, novel dan lain sebagainya. Buku hanya ada di perpustakaan sekolah yang mana isinya hanya berupa buku paket dan buku pelajaran kurikulum. Hal ini sangat tidak menarik minat baca anak-anak untuk berimajinasi secara luas. Dari sinilah kemudian penulis melakukan sebuah penelitian berkaitan dengan Taman Baca Tanah Ombak terhadap literasi baca anak-anak disekitar Pantai Purus yang sebelumnya sangat jauh dari bahan bacaan dan perilaku yang kurang baik.

Peran taman baca yaitu menyediakan bahan bacaan koleksi yang relevan yang disesuaikan dengan kebutuhan penggunanya serta berperan penting dalam menumbuhkan budaya baca masyarakat sekitarnya (Jene, 2013). Sedangkan tujuan taman baca yaitu: (a) meningkatkan minat kegemaran membaca masyarakat; (b) sebagai wadah untuk membangun kegiatan belajar masyarakat; (c) mewujudkan kualitas dan kemandirian masyarakat melalui kegiatan keterampilan sehingga tercipta sumber daya manusia yang handal (Mulyani, 2016).

Membahas mengenai literasi sepertinya merupakan hal yang sudah lumrah di Indonesia, secara sederhana literasi adalah kemampuan membaca, menulis dan berpikir kritis (Musthafa, 2014). Namun literasi tidak hanya selalu terfokus pada kegiatan membaca, menulis, dan berpikir kritis, literasi juga berkaitan dengan kemampuan menggunakan suatu hal sesuai dengan manfaatnya dan takarannya dengan baik dan bijak. Permasalahan literasi Indonesia diharapkan kita dapat mengubah kebiasaan buruk menjadi kebiasaan yang baik yang dapat meningkatkan literasi baca masyarakat Indonesia seperti dengan memanfatkan teknologi. Kita dapat membaca dan mengetahui segala hal mengenai informasi dan pengetahuan dengan mudah dan cepat, kita dapat mengubah kebiasaan-kebiasaan tersebut menjadi lebih baik. Salah satu cara menguasai literasi adalah dengan menanamkan kebiasaan membaca pada anak. Membaca akan memberikan informasi mengenai suatu hal dan pengetahuan. Fondasi untuk menguasai semua ilmu adalah dengan kesenangan dan kebiasaan membaca (Sumardi, 2011). Untuk mengetahui berbagai 
informasi dan pengetahuan kita harus gemari membaca dan tanamkan kebiasaan membaca sejak dini pada anak. Sesuatu yang biasa dilaksanakan akan terbiasa dengan sendirinya sehingga membaca menjadi suatu hal yang tidak dapat dipisahkan dari diri seorang anak.

Inilah gambaran yang dilakukan oleh Taman Baca Tanah Ombak yang berlokasi di Kampung Purus III, Kota Padang, Sumatera Barat. Taman baca merupakan sebuah tempat atau wadah yang didirikan dan dikelola baik oleh masyarakat maupun pemerintah dalam rangka penyediaan akses layanan bahan bacaan bagi masyarakat sekitar sebagai perwujudan konsep pembelajaran sepanjang hayat untuk mendukung kualitas hidup masyarakat sekitar taman baca (Kemendiknas, 2014). Jadi taman baca merupakan suatu lembaga yang diciptakan oleh masyarakat itu sendiri maupun pemerintah yang mana tujuannya adalah untuk meningkatkan literasi baca masyarakat sekitarnya. Lokasi Taman Baca Tanah Ombak tidak tergolong luas namun sangat unik dan menarik untuk anak-anak. Taman Baca ini berada pada pemukiman masyarakat yang tidak jauh dari pesisir pantai Purus, Padang, Sumatera Barat. Masyarakat disana yang memiliki latar belakang ekonomi rata-rata menengah kebawah yang bermata pencarian sebagai nelayan dan pedagang memiliki perilaku anak-anak yang jauh dari etika dalam berbicara. Inilah yang ingin diwujudkan Taman Baca Tanah Ombak untuk menjadikan generasi Indonesia menjadi lebih baik dalam berkarakter serta menciptakan literasi baca di Kampung Purus.

Berdasarkan kajian terdahulu, literasi tumbuh dan berkembang pada anak sejak dini melalui karya sastra yang bersifat kreatif dan imajinatif sehingga memiliki daya tarik tersendiri bagi anak-anak diantaranya dalam bentuk dongeng dan juga bisa dalam bentuk lain. Dongeng dapat membentuk kepribadian dan moralitas, sehingga berpengaruh positif. Dongeng terdiri dari aspek perkembangan kejiwaan dan sarana bagi anak untuk belajar tentang berbagai emosi, perasaan dan nilai moral dan menambah pengalaman belajar anak dalam memahami karakter tokoh dan dapat menilai mana yang dijadikan teladan sekaligus sebagai panutan. (Sumaryanti, 2018)

Berdasarkan hasil penelitian sebelumnya peneliti menyatakan dogeng merupakan salah satu cara yang dapat digunakan sebagai daya tarik untuk membuat anak-anak senang dan gemar membaca serta membentuk kepribadian anak untuk mempelajari emosi, karakter tokoh dan sebagainya. Cara ini terbukti dapat membuat simpati anak dalam meningkatkan literasi baca. Namun berbeda dengan Taman Baca Tanah Ombak, taman baca ini lebih memperluas kegiataannya tidak hanya berdongeng saja akan tetapi juga dalam bentuk kegiatan lain berupa 
mewarnai, menggambar, bercerita, mengaji, menjahit, membordir, serta bermain permainan tradisional. Tidak hanya mengembangkan semangat literasi namun juga memperkenalkan permainan tradisional serta meningkatkan jiwa rohani anak-anak. Penelitian ini membuktikan bahwa ketertarikan anak-anak terhadap buku tidak terlepas dari cara kita yang kreatif dan inovatif dalam mengembangkan segala kegiatan sehingga anak-anak secara tidak langsung ingin datang dan membaca ke Taman Baca Tanah Ombak.

Untuk itu peran kita sebagai mahasiswa dan segala komponen yang berperan penting dalam lingkup agen perubahan. Inilah yang harus kita lakukan perubahan karena literasi baca tidak akan berkembang lebih baik jika hanya memanfaatkan peran perpustakaan dengan cara menunggu pemustaka yang datang kemudian membaca buku, kegiatan ini sudah kuno untuk zaman yang sudah canggih saat ini. Dengan cara melakukan hal yang berbeda, kreatif serta inovatif untuk menarik simpati masyarakat dan anak-anak menjadi gemar membaca. Kita harus mampu memberikan perubahan kepada Indonesia. Pentingnya sebagai penggerak literasi merupakan langkah awal bagi kita minimal untuk mempertahankan budaya bangsa kita sendiri, tidak hanya literasi baca akan tetapi juga literasi media, literasi numerasi, literasi sains, literasi finansial, literasi budaya dan kewargaan. Dengan begitu diharapkan generasi masa depan bangsa dapat terdidik dengan baik.

Tujuan penelitian ini adalah untuk mengetahui peran Taman Baca Tanah Ombak terhadap literasi baca anak di Kampung Purus. Strategi Taman Baca Tanah Ombak dalam meningkatkan minat baca anak-anak yang orangtuanya rata-rata memiliki keterbatasan ekonomi dan tinggal di rumah-rumah yang semi permanen, kumuh serta memiliki kebiasaan yang buruk.

\section{B. TINJAUAN PUSTAKA}

Taman baca masyarakat merupakan sarana untuk menunjang kegiatan pembelajaran bagi masyarakat umum, sehingga menjadi sumber informasi yang berguna terhadap berbagai keperluan, memberi layanan yang berkaitan dengan informasi tertulis, digital, maupun media lainnya. Semakin banyak berdirinya taman baca masyarakat, semakin besar kemungkinan masyarakat pembaca pelayanan pemenuhan kebutuhan informasi lebih merata (M, 2017). Taman baca merupakan salah satu program pembangunan pendidikan yang merupakan pengembangan program budaya baca dan perpustakaan, program ini bertujuan mendorong terwujudnya masyarakat pembelajar sepanjang hayat melalui peningkatan budaya baca serta 
penyediaan bahan bacaan yang berguna bagi aksarawan baru, maupun anggota masyarakat yang membutuhkan pengetahuan dan peningkatan keterampilan demi meningkatkan wawasan dan produktifitas masyarakat (Rahman, 2017). Jadi berdasarkan pendapat diatas dapat disimpulkan bahwa taman baca masyarakat merupakan sarana yang dapat dijadikan sebagai sumber informasi, menambah pengetahuan serta wawasan anggota disekitar taman baca tersebut.

Peran taman baca masyarakat antara lain: (a) peranan media yaitu menghubungkan sumber informasi dan ilmu pengetahuan yang terdapat didalam kolesi yang dimiliki, (b) peranan sebagai sarana yaitu menjalin komunikasi antara sesama pemakai dan penyelenggara taman baca dengan masyarakat, (c) berperan sebagai lembaga yang mengembangkan minat baca, gemar membaca, kebiasaan membaca, budaya baca, melalui bahan bacaan sesuai dengan keinginan masyarakat, (d) berperan aktif sebagai fasilitator, mediator, motivator bagi mereka yang ingin mencari, memanfaatkan ilmu pengetahuan dan pengalamannya, (e) sebagai agen perubahan, agen pembangunan dan agen kebudayaan manusia, (f) berperan sebagai lembaga pendidikan nonformal bagi masyarakat dan pengunjung taman baca, (g) petugas taman baca berperan sebagai pembimbing yang memberikan konsultasi kepada pemakai, dan pembinaan serta menanamkan pemahaman pentingnya taman baca masyarakat bagi orang banyak, (h) menghimpun dan melestarikan koleksi agar tetap dalam keadaan baik semua karya manusia yang tak ternilai harganya (Rahman, 2017). Menurut Direktorat Jendral Pendidikan Anak Usia Dini, tujuan taman baca masyarakat adalah untuk meningkatkan kemampuan aksara, keterampilan membaca, membangun masyarakat membaca, mengembangkan minat membaca, dan mewujudkan kualitas kemandirian masyarakat yang berpengetahuan, berketerampilan, berbudaya maju dan beradab serta mendorong masyarakat mewujudkan pembelajaran sepanjang hayat. Sedangkan manfaat taman baca adalah (a) menumbuhkan minat, kecintaan dan kegemaran membaca; (b) memperkaya pengembangan belajar dan pengetahuan; (c) membantu pengembangan kecakapan membaca; (d) menambah wawasan tentang perkembangan ilmu pengetahuan dan teknologi; (e) serta meningkatkan pemberdayaan masyarakat (Rahman, 2017). Persis dengan perpustakaan umum taman baca masyarakat memiliki sasaran yaitu seluruh lapisan masyarakat yang terdapat di sekitar taman baca tersebut, sehingga fungsi pembelajaran sepanjang hayat oleh masyarakat dapat di terapkan. Dampak taman baca masyarakat terhadap kemajuan literasi masyarakat diantaranya kecakapan personal, kecakapan akademik, dan kecakapan vokasional (Indriyani,2017). 
Sebuah keluarga yang menerapkan budaya membaca, akan lebih mudah mengkondisikan anggota keluarganya untuk mempunyai minat dalam membaca. Hal ini diantaranya bisa ditandai dengan adanya ruang baca dengan sejumlah koleksi buku dalam sebuah keluarga, menjadi anggota perpustakaan secara rutin meminjam koleksi perpustakaan, mempunyai agenda untuk membeli buku setiap bulan, maupun jadwal tersendiri untuk membaca. Ketika budaya membaca ini sudah terbentuk dalam suatu keluarga, maka daerah dimana keluarga tersebut menetap akan terlokalisasi sebagai daerah yang mempunyai budaya membaca (Hidayanto, 2013). Pendapat tersebut membuktikan bahwa budaya membaca atau literasi baca suatu masyarakat dimulai dari suatu keluarga dalam suatu daerah. Jika budaya membaca suatu masyarakat dalam suatu daerah sangat bagus maka literasi baca didaerah tersebut sangat bagus.

Berdasarkan pendapat diatas dapat diasumsikan bahwa taman baca masyarakat penting untuk memberikan edukasi dan pembelajaran sepanjang hayat bagi masyarakat serta memberikan pelayanan informasi baik secara tercetak maupun dalam bentuk digital dengan tujuan untuk memenuhi kebutuhan informasi masyarakat dan menumbuhkan minat baca masyarakat dengan cara memberikan pelayanan yang kreatif dan inovatif.

Penelitian terdahulu mengenai literasi telah banyak dilakukan karena memang literasi merupakan permasalahan yang sangat penting untuk diperbincangkan dan mencari jalan keluar dari permasalahan literasi tersebut. Tidak hanya literasi baca, namun juga literasi media, literasi informasi, literasi media, literasi sosial, literasi komputer dan sebagainya. Itu semua menyesuaikan dengan perkembangan zaman yang menuntut generasi muda untuk harus tahu dan cerdas dalam melakukan sesuatu. Generasi muda harus memiliki keterampilan literasi karena literasi berpengaruh penting bagi keberhasilan generasi muda. Keterampilan literasi yang baik akan membantu generasi muda dalam memahami informasi baik lisan maupun tertulis. (Irianto \& Febrianti, 2017)

Hal ini penting bagi generasi bangsa dalam memilah informasi yang terpercaya dan informasi yang belum dapat dibuktikan kebenarannya. Jika generasi bangsa tidak cerdas dalam mengatasi suatu berita yang belum bisa dipastikan kebenarannya dan mudah di hasut oleh orangorang yang ingin menghancurkan negara, maka terjadilah perpecahan di negara kita. Banyak usaha dan segala bentuk kegiatan dilakukan untuk memperbaiki literasi anak-anak Indonesia, diantara banyaknya penelitian tersebut salah satunya adalah Fichry Arifin dan Marlini 
berdasarkan pembahasan dari masalah tersebut disimpulkan, yaitu (a) adanya Taman Baca Masyarakat Tanah Ombak di Purus III sangat bermanfaat bagi masyarakat sekitar Taman Bacaan Masyarakat dalam infrastruktur akses ke Taman Baca Masyarkat dan fasilitasnya, banyaknya pejabat datang ke Taman Baca Masyarakat dan menyumbangkan berbentuk uang dan fasilitas, (b) kendala masyarakat dalam pemanfaatan Taman Baca Masyarakat Tanah Ombak yaitu, susahnya mendapatkan bermacam koleksi buku anak-anak seperti dongeng, buku cerita rakyat dan lain-lain, sulitnya mengajak anak-anak yang belum akrab dengan kegiatan-kegiatan seperti literasi Taman Bacaan Masyarakat, kurangnya relawan, kurang terampilnya petugas Taman Baca Masyarakat Tanah Ombak, dan (c) upaya dalam mengatasi kendala berupa memanfaatkan jaringan toko buku dan penerbit di luar daerah, melakukan kegiatan dan pertujukan, mendatangkan relawan, menjalin kerja sama dalam mengajarkan petugas Taman Baca Masyarakat (Arifin \& Marlini, 2017).

Penelitian ini memiliki kelebihan yaitu membahas secara lengkap koleksi apa saja yang tersedia di Taman Baca Tanah Ombak, transportasi apa saja yang dapat menuju Taman Baca Tanah Ombak dan kendala yang di hadapi Taman Baca Tanah Ombak. Akan tetapi penelitian tersebut belum membahas mengenai dampak apa saja yang ditimbulkan Taman Baca Tanah Ombak terhadap literasi anak di Kampung Purus III yang memiliki latar belakang perilaku yang tidak baik. Peneliti akan menyempurnakan penelitian sebelumnya mengenai peran kita sebagai mahasiswa dan komponen yang berperan dalam meningkatkan literasi baca untuk ikut berpartisipasi sebagai relawan dalam berbagai komunitas yang mendukung literasi baca anakanak pada suatu daerah atau perkotaan serta cara kreatif agar anak-anak tertarik untuk membaca seperti berdongeng, bernyanyi, bercerita, permainan tradisional dan sebagainya.

\section{METODE PENELITIAN}

Penelitian yang berlokasi di Kampung Purus III, Kota Padang, Sumatera Barat ini menggunakan metode penelitian deskriptif menggunakan pendekatan kualitatif. Informan dalam penelitian ini adalah Pendiri Taman Baca Tanah Ombak yaitu bapak Yusrizal. Penelitian ini dilakukan pada November-Desember 2019. Tujuan penelitian deskriptif adalah memberikan gambaran berdasarkan fakta yang akurat yang diperoleh selama penelitian. Subjek dalam penelitian ini adalah anak-anak yang tinggal di sekitar Taman Baca Tanah Ombak, sedangkan objek penelitiannya adalah Taman Baca Tanah Ombak, Padang, Sumatera Barat. Teknik 
pengumpulan data dalam penelitian kualitatif ini dilakukan dengan beberapa cara, yaitu: (1) observasi, teknik ini merupakan teknik untuk memperoleh keterangan berupa informasi dengan cara meneliti secara langsung ke Taman Baca Tanah Ombak berkaitan dengan literasi anak. (2) wawancara, peneliti melakukan wawancara dengan key informan dengan memberikan beberapa pertanyaan dengan bebas namun terstruktur sesuai dengan pola wawancara yang peneliti lakukan. Peneliti datang ke lokasi tujuan kemudian melakukan perkenalan dan menyatakan maksud tujuan untuk mendapatkan informasi yang akurat mengenai Taman Baca Tanah Ombak terhadap literasi anak. Kemudian peneliti menyaring informasi-informasi yang peneliti perlukan. (3) kepustakaan yaitu mencari literature mengenai literasi pada sumber yang akurat. Teknik pengumpulan data merupakan langkah yang paling strategis dalam penelitian karena tujuan utama dalam penelitian adalah mengumpulkan data dan mendapatkan data. Tanpa mengetahui teknik pengumpulan data maka peneliti tidak akan medapatkan data yang memenuhi standar yang telah ditetapkan. (Sugiyono, 2011). Metode analisis data yang digunakan peneliti adalah model interaktif Miles, Huberman dan Saldana, komponen yang digunakan dalam analisis data Miles, Huberman dan Saldana yaitu: kondensasi data, penyajian data dan penarikan kesimpulan (Miles, Huberman, \& Saldana, 2014).

\section{HASIL DAN PEMBAHASAN}

Dalam upaya menghasilkan suatu temuan penelitian maka peneliti menggunakan wawancara sebagai penelitian secara mendalam. Berikut ini tabel pertanyaan penelitian saat melakukan wawancara di Taman Baca Tanah Ombak untuk memperjelas temuan Penelitian.

Tabel 1. Pertanyaan Penelitian dan Temuan Penelitian

\begin{tabular}{|c|c|c|c|}
\hline No & Variabel & Pertanyaan Penelitian & Temuan Penelitian \\
\hline \multirow[t]{3}{*}{1} & \multirow{3}{*}{$\begin{array}{l}\text { Taman Baca Tanah } \\
\text { Ombak dalam } \\
\text { meningkatkan literasi } \\
\text { baca anak Pantai } \\
\text { Purus }\end{array}$} & $\begin{array}{l}\text { 1. Pendiri Taman Baca Tanah } \\
\text { Ombak? }\end{array}$ & $\begin{array}{l}\text { Bapak Yusrizal dan } \\
\text { Suhendri. }\end{array}$ \\
\hline & & $\begin{array}{l}\text { 2. Lokasi Taman Baca Tanah } \\
\text { Ombak? }\end{array}$ & $\begin{array}{l}\text { Kampung Purus } \text { III, Kecamatan } \\
\text { Padang Barat, Kota Padang, } \\
\text { Sumatera Barat. }\end{array}$ \\
\hline & & $\begin{array}{l}\text { 3. Kegiatan yang dilakukan di } \\
\text { Taman Baca Tanah Ombak? }\end{array}$ & $\begin{array}{l}\text { Membaca, menulis, menggambar, } \\
\text { bercerita, berdongeng, belajar } \\
\text { mengaji dan sholat berjamaah, } \\
\text { belajar alat musik, belajar } \\
\text { membordir, menjahit, perpustakaan }\end{array}$ \\
\hline
\end{tabular}




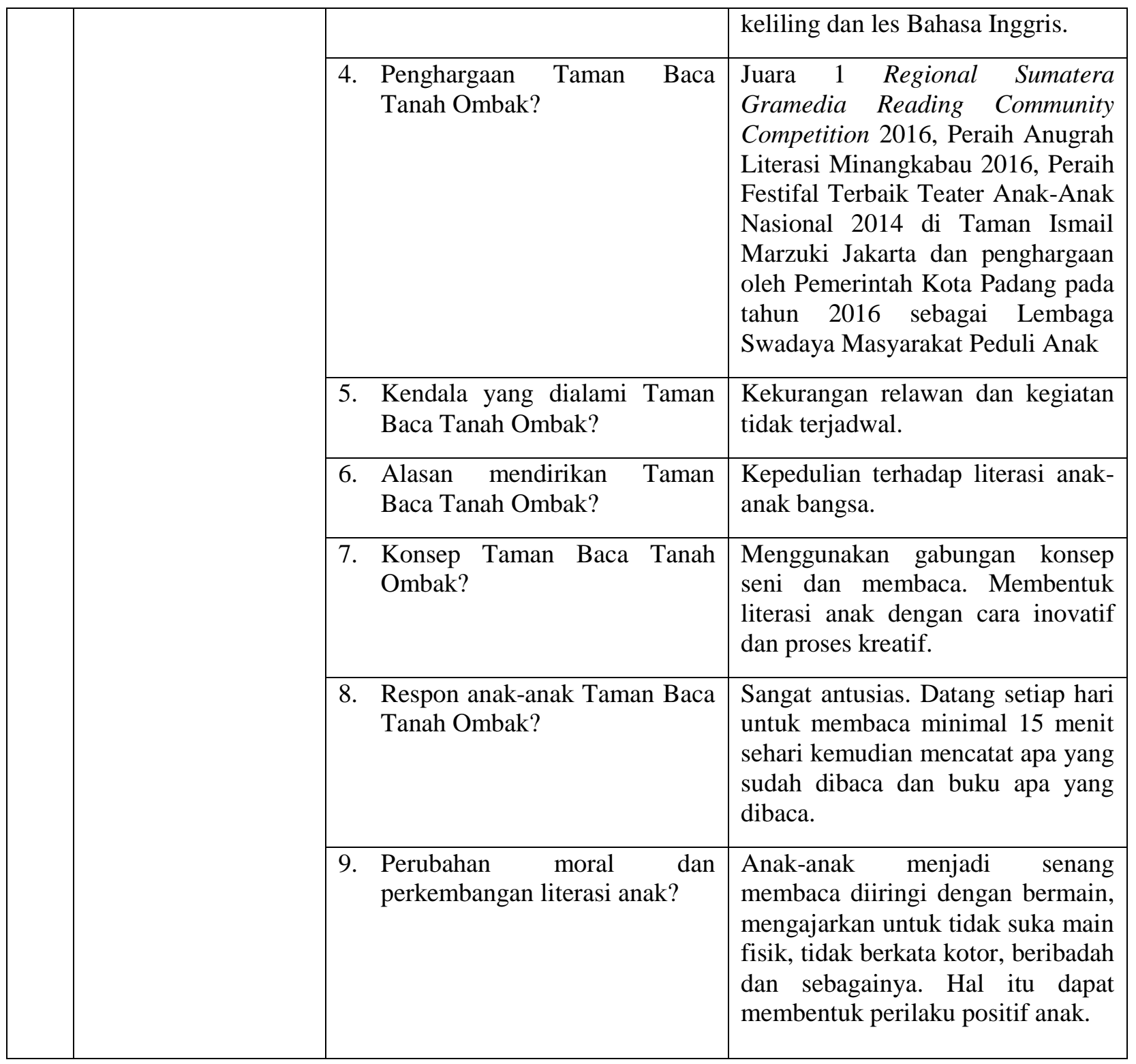

Sumber: Hasil penelitian, 2019

Taman baca Tanah Ombak yang dibangun oleh Bapak Yusrizal dan Bapak Syuhendri berlokasi di Kampung Purus III, Kota Padang, Sumatera Barat. Taman bacaan ini mulai merintis pada tahun 1993 namun baru terealisasikan pada akhir tahun 2014. Taman Baca ini bertujuan untuk memberikan kesadaran kepada masyarakat perkampungan dengan cara mengkombinasikan dengan unsur seni yang lebih kreatif dan menarik simpati anak-anak. Taman baca ini adalah hybrid yaitu gabungan dari dua cara yaitu seni grup teater dan taman baca. Grup teater ini mengalami kemunduran lalu pindah lokasi ke Kampung Purus. Rencana ini berjalan dengan baik 
karena objek yang ada di perkampungan yaitu anak-anak sesuai dengan taman baca yang akan didirikan.

Pendiri Taman Baca Tanah Ombak Bapak Yusrizal mengatakan bahwa, “Konsep yang diciptakan sangat sederhana yaitu dengan mencoba menciptakan anak-anak yang mencintai buku dan membangun karakter yang lebih baik, karena memang latar belakang perilaku anak-anak di Kampung Purus memiliki dampak negatif bagi generasi muda Kampung Purus. Hal ini dilakukan dengan cara mengajarkan kepada anak-anak untuk tidak berkata-kata kasar, tidak boleh main fisik seperti bertengkar, etika, sopan santun dan belajar mendengarkan. Selain itu Taman Baca Tanah Ombak mengajarkan anak-anak menulis, membaca, mengambar, mewarnai, les bahasa Inggris yang dikreasikan dalam bentuk kesenian, teater dan musik. Taman baca ini adalah bentuk kerja keras Bapak Yusrizal dan Bapak Syuhendri tanpa memasukan proposal dan bantuan kemanapun. Semuanya hanya berawal dari spirit atau semangat namun tidak menghambat penghargaan dan prestasi anak-anak Tanah Ombak”. (Yusrizal, wawancara, November 10, 2019).

Berbeda dengan pekerjaan, Bapak Yusrizal memiliki cita-cita yang bergerak dalam bidang seni untuk menjadikan Indonesia yang memiliki minat baca yang bagus dan memiliki pengetahuan yang bagus pula namun tidak untuk digaji. Bapak Yusrizal bergerak dalam bidang seni teater yang sangat dekat dengan membaca kemudian timbul kesadaran bahwa membaca itu penting dan anak-anak juga harus tumbuh menjadi anak-anak yang suka. Awalnya Taman Baca Tanah Ombak ini sempat menerima penolakan dari masyarakat. Hal ini dikarenakan masyarakat yang tidak akrab dengan membaca, tidak peduli dengan sikap dan sopan santun, tidak peduli dengan sekolah dan pendidikan, perilaku yang tidak baik, namun dengan usaha dan kerja keras, perlahan-lahan dapat memberikan pemahaman dengan proses yang kreatif serta sosialisasi yang terus dijalankan sehingga masyarakat dapat menerima keberadaan Taman Baca Tanah Ombak.

Inilah tujuan yang diharapkan yaitu untuk menciptakan anak-anak yang pandai menulis, gemar membaca, senang menggambar, bercerita dan berdongeng. Bahkan anak-anak ini memiliki buku puisi, essai dan prosa. Mereka diajarkan untuk membaca minimal 15 menit per hari. Biasanya setelah pulang sekolah tanpa disuruh mereka akan datang kesini untuk membaca dan menulis. Nanti setelah dibaca mereka akan menuliskan buku apa saja yang telah dibaca pada hari ini, kapan waktu membaca dan setiap akhir bulan pembaca terbanyak akan diberi apresiasi 
berupa hadiah. Taman Baca Tanah Ombak berbeda dengan konsep perpustakaan yang mengharuskan anggota yang datang untuk diam, hening, sepi dan senyap. Namun di Taman Baca Tanah Ombak bertolak belakang 360 derajat. Tidak hanya membaca disini juga bisa dijadikan sebagai tempat bermain anak-anak. Jadi disini kalau bisa ribut, sangat ribut karena ada yang beryanyi, mendongeng, bermain dan sebagainya. Hal ini merupakan bentuk pendekatan terhadap anak untuk menyukai lingkungan karena kita tidak bisa memaksakan anak harus membaca, sedikit demi sedikit dengan bermain mereka melihat buku, mungkin hari ini mereka tidak tertarik namun seiring waktu mereka akan meraih buku yang ada disekitarannya. Buku adalah tujuan utama Taman Baca Tanah Ombak namun tidak menggunakan buku sebagai tujuan utama tapi justru kreatifitas sepeti seni, musik, dongeng dan bermain.

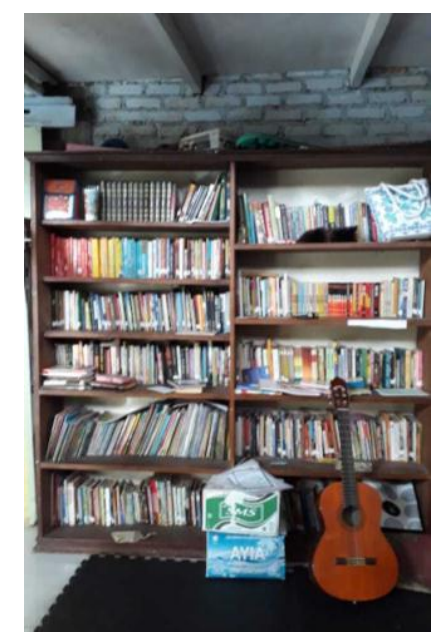

Gambar 1. Koleksi buku Taman Baca Tanah Ombak Sumber: Hasil penelitian, 2019

Ditemui saat wawancara Bapak Yusrizal mengatakan bahwa, "Taman Baca Tanah Ombak tidak hanya untuk belajar membaca, menulis bercerita atau sekedar bermain. Taman baca ini memiliki kegiatan spiritual seperti belajar mengaji dan sholat berjamaah. Hal ini penting untuk ditanamkan sejak dini kepada anak-anak bahwa tidak hanya dunia saja yang kita raih kesuksesannya namun kita juga harus sukses dalam urusan akhirat. Seperti yang terdapat pada sila pertama yaitu Ketuhanan Yang Maha Esa. Menanamkan sejak dini kepada anak-anak untuk mengingat pencipta merupakan langkah yang tepat dalam mengajarkan nilai karakter terhadap anak. Mulai dari cara bersikap terhadap yang lebih tua, sopan santun, dan etika dalam bergaul. Tidak hanya anak-anak orangtua juga ikut mengaji dan sholat berjamaah di Taman Baca Tanah Ombak. Siapapun yang datang bisa belajar disini, baik belajar membaca, menulis, menjahit atau 
belajar alat musik yang telah disediakan. Seperti pada awal mulanya Taman Baca Tanah Ombak ini merupakan kombinasi dari grup teater kesenian. Hal ini dijadikan sebagai kreativitas karena jika semata anak-anak disuruh membaca saja pasti tidak akan mau. Jadi kita harus mampu memberikan inovasi dan kreativitas tanpa paksaan untuk membaca". (Yusrizal, wawancara, Desember 11, 2019).

Di Taman Baca Tanah Ombak masyarakat sekitar bisa belajar menjahit, membordir sebagai bentuk kerajinan tangan atau berwirausaha masyarakat. Dunia literasi tidak hanya terfokus kepada membaca dan menulis saja akan tetapi juga melibatkan kepada pemberdayaan masyarakat salah satunya mengajar menjahit dan membordir. Namun pelaksanaannya kurang efektif karena masyarakat lebih suka terhadap sesuatu yang instan padahal tujuan awalnya adalah kepandaian dan kemampuan bukan untuk menajadi seorang penjahit akan tetapi memiliki kemampuan menjahit yang dapat bermanfaat untuk kehidupan individu masing-masing.

Taman baca Tanah Ombak juga mengajarkan permainan tradisional yang dilakukan secara bersama-sama. Dengan memberitahukan bahwa bermain smartphone dibatasi. Boleh bermain smartphone akan tetapi dibatasi. Misalnya apabila anak-anak tidak suka menulis dengan pena, boleh menulis menggunakan smartphone yang terpenting mereka kreatif asalkan tidak terjebak dalam dunia digital yang menjadikan anak-anak bodoh. Seperti yang terjadi saat ini anak-anak sangat candu dalam bermain game yang didapatinya melalui smartphone, seharusnya ini sudah menjadi lampu merah bagi orangtua untuk membatasi dan mengawasi anak-anak dalam menggunakan smartphone. Kadang-kadang disaat kita lengah anak-anak dapat terpengaruhi oleh dunia maya yang sangat besar memberikan pengaruh negatif jika tidak didampingi seperti konten negatif dan sebagainya.

Taman Baca Tanah Ombak memiliki perpustakaan keliling dengan cara menjajakan buku menggunakan motor kemudian membuka lapak pada suatu tempat yang ternyata banyak anakanak yang tertarik untuk datang membaca buku. Anak-anak sangat antusias melihat kedatangan perpustakaan keliling. Tidak hanya membaca, kegiatan mendongeng akan dilakukan bagi anakanak yang tidak suka membaca. Perpustakaan keliling diresmikan oleh Najwa Shihab yaitu Duta Baca Indonesia ketika ia berkunjung ke Taman Baca Tanah Ombak. Menjadi orang Indonesia bukan berarti kita tidak boleh belajar bahasa asing. Di Taman Baca Tanah Ombak anak-anak 
diajarkan untuk mengenal bahasa asing yaitu Bahasa Inggris. Bahasa ini adalah bahasa Internasional yang wajib untuk diajarkan kepada generasi muda Indonesia.

Siapa yang menuai benih pasti akan memperoleh hasil. Begitu juga perjalanan panjang Taman Baca Tanah Ombak memiliki banyak prestasi dan penghargaan dari berbagai lembaga dan artis ternama lainnya. Penghargaan yang diraih tidak terlepas dari kerja keras dan usaha yang dilakukan oleh anak-anak Taman Baca Tanah Ombak. Penghargaan yang pernah diraih diantaranya Juara 1 Regional Sumatera Gramedia Reading Community Competition 2016, Peraih Anugrah Literasi Minangkabau 2016, Peraih Festifal Terbaik Teater Anak-Anak Nasional 2014 di Taman Ismail Marzuki Jakarta dan penghargaan oleh Pemerintah Kota Padang pada tahun 2016 sebagai Lembaga Swadaya Masyarakat Peduli Anak.

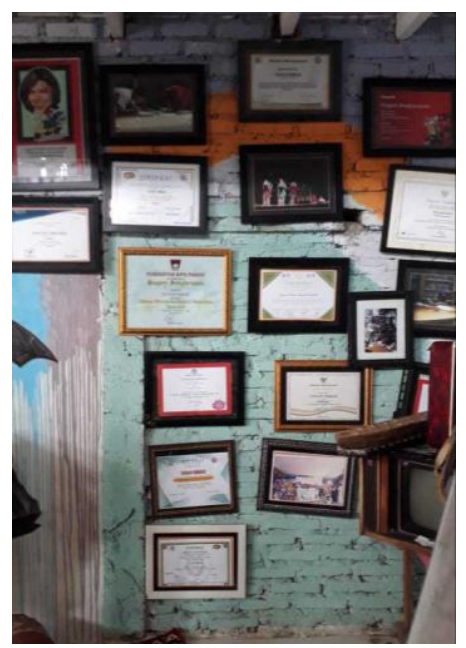

Gambar 2. Penghargaan dari berbagai lembaga dan artis ternama Sumber: Hasil penelitian, 2019

Relawan adalah seseorang yang bekerja dengan memberikan waktu secara cuma-cuma dengan setulus hati untuk membantu orang lain tanpa mengharapkan imbalan berupa materi atau finansial. Menjadi relawan di Taman Baca Tanah Ombak tidak hanya belajar menulis, membaca, mendongeng dan sebagainya namun sebagai relawan kita harus mengajarkan nilai-nilai karakter, nilai kejujuran, toleransi, mengajarkan mereka norma-norma dengan cara yang kreatif bukan mendoktrin tapi memandu dengan memberikan pemahaman yang baik yaitu dengan cara bernyanyi, bermain dan sebagainya. Dampaknya bukan hari ini akan tetapi dirasakan di masa yang akan datang. Sekedar datang, bermain, belajar atau hanya untuk menanyakan PR yang mereka dapat dari sekolahnya. Intinya menjadi seorang relawan kita harus menyadari bahwa yang kita lakukan hari ini berguna untuk orang lain. Namun saat ditemui, Bapak Yusrizal 
berkata bahwa, "Saat ini Taman Baca Tanah Ombak terkendala dengan tidak adanya relawan. Hal ini dikarenakan relawan yang sebelumnya telah menyelesaikan studinya. Jadi kita juga tidak bisa menahan mereka untuk tetap tinggal disini”. (Yusrizal, wawancara, Desember 25, 2019).

Terbatasnya relawan menyebabkan kegiatan Taman Baca Tanah Ombak tidak terjadwal. Biasanya sekali tiga bulan anak-anak Taman Baca Tanah Ombak berlatih teater, jika ada panggung mereka akan latihan. Biasanya anak-anak Taman Baca Tanah Ombak memiliki kegiatan satu kali sebulan mengadakan pertunjukan bakat seperti baca puisi, membaca novel dan sebagainya namun terkendala relawan. Sebagai generasi perubahan untuk bangsa, mahasiswa penting menyadari bahwa menumbuhkan sikap sadar dan peduli terhadap anak-anak yang masih jauh dari literasi adalah suatu kewajiban bagi kita. Memiliki jiwa peduli dan sadar akan literasi merupakan poin utama dan terpenting, karena segala kegiatan literasi dapat dijalankan dengan semangat dan pantang menyerah jika seseorang tersebut telah memiliki kesadaran dan jiwa kepedulian terhadap literasi anak bangsa. Tumbuhnya minat literasi tidak akan muncul begitu saja. Perlu dukungan dan dorongan dari berbagai pihak, dimulai dari lingkungan keluarga, sekolah, dan masyarakat. Proses ini akan berjalan dengan kondusif apabila kita giat dan berusaha untuk mencapai tujuan dari literasi. Literasi tidak hanya kita dapatkan dilingkungan sekolah atau perguruan tinggi yang menyediakan perpustakaan saja akan tetapi kita dapat menyadari bahwa literasi dapat dibentuk oleh siapapun selagi memiliki kesadaran akan literasi tersebut. Orang yang memiliki sekolah tinggi belum tentu seorang yang literet namun orang yang tidak sekolah tinggi belum tentu tidak literet. Intinya pengaruh lingkungan berdampak terhadap literasi suatu masyarakat. Untuk itu sebagai mahasiswa Prodi Perpustakaan dan Ilmu Informasi tanamkan sikap literasi pada diri kita dan mari mencoba menyebarkan literasi kepada orang lain. Tidak perlu dalam cakupan besar mulailah dari diri sendiri dan keluarga lalu menciptakan suatu gerakan ditengah-tengah masyarakat dengan menciptakan taman baca atau lapak baca.

Tidak hanya memiliki sikap peduli akan tetapi kita juga harus memiliki kemampuan yang kompeten mengenai suatu bidang yang harus didapatkan dengan menjalankan pendidikan, pelatihan, atau sosialisasi. Memiliki kemampuan tidak kalah penting dengan memiliki jiwa kepedulian, kedua hal ini memiliki hubungan yang berkesinambungan. Jika memiliki kepedulian dan sadar akan literasi namun tidak berkompeten dan tidak paham dengan literasi maka ia akan 
bingung dan tidak paham dengan langkah apa yang harus ia lakukan untuk mengembangkan literasi anak.

Untuk mendapatkan kemampuan yang kompeten dibidang Perpustakaan seseorang tersebut harus menjalankan pendidikan D3 Perpustakaan atau S1 Perpustakaan. Di Indonesia sudah banyak kampus-kampus atau perguruan tinggi yang menyediakan prodi tersebut. Dengan kemampuan yang kompeten seseorang akan mengetahui tindakan apa yang seharusnya ia lakukan saat menghadapi suatu permasalahan baik itu mengenai masalah baca, literasi, perpustakaan dan sebagainya. Seseorang yang telah menyelesaikan studi perpustakaan dianggap telah berkompeten dibidang tersebut. Jika seseorang telah menyelesaikan studinya maka ia dapat dikatakan sebagai seorang pustakawan yang tugasnya ialah mampu memenuhi kebutuhan informasi bagi pemustaka serta memiliki kepedulian terhadap perkembangan literasi dilingkungannya.

\section{E. KESIMPULAN DAN SARAN}

Berdasarkan hasil penelitian dapat disimpulkan bahwa Taman Baca Tanah Ombak dapat mempengaruhi literasi anak Kampung Purus III. Hal tersebut dapat dibuktikan bahwa dengan cara yang kreatif banyak anak-anak yang datang ke Taman Baca untuk belajar membaca, bercerita, menggambar, mengaji, sholat berjamaah, mengaji, belajar alat musik atau hanya untuk sekedar bermain serta berbagai penghargaan yang diraih oleh anak-anak tersebut. Kegiatan ini dapat menjadikan anak-anak memiliki perilaku positif yang mencerminkan generasi yang lebih baik. Masyarakat yang dikenal memiliki sikap yang tidak baik, tidak suka membaca dan berkatakata kotor perlahan dapat berubah dengan kerja keras dan usaha Bapak Yusrizal dan Bapak Syuhendri serta kawan-kawan. Semua itu berasal dari semangat dan cita-cita untuk peduli dengan literasi baca anak-anak yang sudah ada sejak dahulunya. Perjalanan tidak selalu berjalan mulus banyak rintangan yang dihadapi namun dapat dihadapi dengan cara memberikan pemahaman dan sosialisasi kepada masyarakat yang sempat memberikan penolakan terhadap keberadaan Taman Baca Tanah Ombak. Namun hasilnya berbuah manis, Taman Baca Tanah Ombak dapat memberikan pemahaman dan edukasi kepada anak bahwa memiliki perilaku yang baik, sopan dan santun adalah cerminan generasi masa depan. Kepedulian masyarakat, mahasiswa, dan pemerintah sangat berpengaruh dalam meningkatkan literasi baca bagi anakanak Indonesia. Berdasarkan simpulan dari hasil penelitian maka saran dari peneliti untuk Taman 
Baca Masyarakat Tanah Ombak di Purus III Padang sebaiknya menyebarkan pemberitahuan untuk membutuhkan relawan melalui media cetak atau media sosial. Hal ini dapat mengatasi kendala kekurangan relawan. Sedangkan rancangan untuk penelitian selanjutnya dapat meneliti mengenai bagaimana peran mahasiswa agar giat dan aktif dalam meningkatkan literasi baca anak nagari di pelosok negeri.

\section{DAFTAR PUSTAKA}

Arifin, F., \& Marlini. (2017). Pemanfaatan Taman Bacaan Masyarakat Tanah Ombak Di Purus III Padang Sebagai $\begin{array}{llllll}\text { Sumber } & \text { Belajar. } & \text { Jurnal } & \text { UNP } & 5 & \text { (2), }\end{array}$ http://ejournal.unp.ac.id/index.php/iipk/article/download/8423/6490.

Hidayanto, J. (2013). Upaya Meningkatkan Minat Baca Masyarakat Melalui Taman Bacaan Masyarakat Area Publik Di Kecamanatan Ungaran Timur Kabupaten Semarang. Fakultas Ilmu Pendidikan. Univeristas Negeri Semarang: Semarang.

Indriyani, I. (2017). Pengelolaan Taman Baca Masyarakat Berbasis Kekeluargaan Dan Dampaknya Terhadap Kemajuan Literasi Masyarakat. Fakultas Ilmu Pendidikan. Universitas Negeri Semarang: Semarang.

Irianto, P. O., \& Febrianti, L. Y. (2017). Pentingnya Penguasaan Literasi Bagi Generasi Muda Dalam Menghadapi MEA. jurnal UNISSULA 1 (1), 640-647. http://jurnal.unissula.ac.id/index.php/ELIC/article/view/1282.

Jene, O. C. (2013). Peran Taman Bacaan Masyarakat Dalam Menumbuhkan Budaya Baca Anak Di Taman Bacaan Masyarakat "Mortir" Banyumanik-Semarang. Jurnal Ilmu Perpustakaan, 1-10. http://ejournals1.undip.ac.id/index.php/jip

Kemendiknas. (2014). Petunjuk Teknis Program Pembangunan Budaya Baca melalui Penguatan Taman Bacaan Masyarakat. Jakarta: Direktorat Pembinaan Pendidikan Masyarakat.

M, S. H. (2017). Peran Taman Bacaan Masyarakat (TBM) Denassa Dalam Menumbuhkan Minat Baca Masyarakat Di Borongtala Kecamatan Bontonompo Kabupaten Gowa. Fakultas Adab dan Humaniora. Universitas Negeri Islam Makassar: Makassar.

Miles, Huberman, \& Saldana. (2014). Qualitative Data Analysis . America: SAGE Publications.

Mulyani, I. P. (2016). Peran Taman Bacaan Masyarakat Cerdas Dalam Menigkatkan Minat Belajar Masyarakat Di Desa Wringinagung Kecamatan Doro Kabupaten Pekalongan. Fakultas Ilmu Pendidikan. Universitas Negeri Semarang: Semarang.

Musthafa, B. (2014). Literasi Dini dan Literasi Remaja: Teori, Konsep dan Praktik. Bandung: CREST.

Rahman, A. P. (2017). Peranan Taman Baca Kecamatan Dalam Melayani Kebutuhan Belajar Masyarakat Di Kelurahan Paropo, Kecamatan Panakkukang, Kota Makassar. Fakultas Adab dan Humaniora. UIN Alauddin Makassar: Makassar.

Saputri, K., Fauziah, \& Nurhaidah . (2017). Faktor-Faktor Yang Mempengaruhi Literasi Anak kelas 1 SD Negeri 20 Banda Aceh. Jurnal Ilmu Pendidikan Guru Sekolah Dasar FKIP Unsyiah 2 (1), 98-104. http://www.jim.unsyiah.ac.id/pgsd/article/viewFile/2537/2030

Sugiyono. (2011). Metode Penelitian Kualitatif. Bandung: Alfabeta Bandung.

Sumardi. (2011). Rahasia menjadi Siswa Unggul. Jakarta: Erlangga. 
Sumaryanti, L. (2018). Membudayakan Literasi Pada Anak Usia Dini Dengan Metode Mendongeng. AL-ASASIYYA: Journal Basic of Education 3 (1), 117-125. http://journal.umpo.ac.id/index.php/alasasiyya/article/download/1332/845 